\title{
Development of an Instructional System Design Model as a Guideline for Lecturers in Creating a Course Using Blended Learning Approach
}

\author{
https://doi.org/10.3991/ijim.v14i14.14411 \\ Uwes Anis Chaeruman ( $\left.{ }^{凶}\right)$, Basuki Wibawa, Zulfiati Syahrial \\ State University of Jakarta, Jakarta, Indonesia \\ uwes@unj.ac.id
}

\begin{abstract}
Blended learning is not just merely blending face-to-face and online learning. The biggest challenge is making the right mix of relevant learning settings and teaching strategies to meet the learning outcomes. The latest study showed that research focusing on the instructional system design (ISD) model developments, especially related to blended learning approach, were still limited. This study aims to develop an ISD model that can provide a guideline for lecturers in creating a good course using a blended learning approach. This study applied a formative research method. A series of formative evaluation using several formative data collection techniques were used. They were expert review, one-to-one evaluations, and field tests. This study involved 242 respondents, consists of 7 instructional design and e-learning experts, and 235 lecturers. After conducted a series of formative evaluation stages, respondents able to create a good quality course using the ISD model developed. Most of them get fair and low scores on the field test 1 . The score increased significantly on the field test 2 , where $33.6 \%$ get excellent scores, $48.2 \%$ get good scores, and $28.2 \%$ get fair scores. The score also increased significantly on field test 3 $60.5 \%$ get excellent scores, $33.6 \%$ get good scores, and only $5.9 \%$ get poor scores. Hence, it can be concluded that the ISD model developed is feasible and usable. It can be used by higher education lecturers in Indonesia as a guideline in creating a course using blended learning approach.
\end{abstract}

Keywords-Asynchronous learning, blended learning, e-learning, instructional system design, synchronous learning.

\section{Introduction}

E-learning, with its various terms [1], has emerged since 2002 [2]. One of the terms is called blended learning. Blended learning, conceptually, is not merely the combination of face-to-face and online classes. It is art and science of integrating various appropriate learning sources and activities in which the students can interact and brainstorm together [2]. A recent study showed that some essential focuses in designing blended learning were related the what, the when, and the how [3]. This ability is crucial and imperative for teachers, lecturers, and instructional designers in 21 st cen- 
tury era. However, the lecturers often find it difficult, not because of the lack of knowledge and skill, but also the conventional learning mindset that has been their daily routines [4]. Another study also showed the same result. Kenney concluded that effective integration online and face-to-face learning is an essential aspect of designing blended learning [5]. The blended learning design depends on the lecturer's ability to design a good instructional system [6]. Recent studies showed that well designed and implemented blended learning can enhance self-regulated and self-directed learning skills of the students [7].

To be able to create a course with the blended learning approach, lecturers need an instructional system design (ISD) model as a guideline. Nevertheless, the latest studies showed that among many studies on blended learning, $41.2 \%$ of them focused on blended learning strategy, with subtopics related to models, strategies, design process, implementation, and course structure. But, among them, only $3.5 \%$ related to the ISD model development [8]. Whereas, the existence of ISD models is crucial for practitioners or lecturers as a reference in designing good quality instruction, including instruction with the blended learning approach.

ISD is an activity of designing an instructional system program from the start to the end [9]. It is also known as a systematic and iterative process used to develop an educational or training program [10]. Instructional designers, lecturers, teachers, or instructors need models or ISD models as a guideline. Model is a simple representation of a form, process, and function of the physical and the idea of complex phenomena [10]. So, as a guideline, an ISD model should have some components as its subsystem. Each component has different specific functions, but should inter-related one each other. The model also should provide a step by step guidance or procedures [11]. The last, an ISD model should be developed and tested in the context where the model itself will be used and implemented [12].

This study intended to develop an ISD model that will be used by lecturers in the context of higher education institutions in Indonesia. Directorate General of Learning and Student Affairs, Ministry of Research, Technology, and Higher Education (MoRTHE), Indonesia, since August 2014 has been implementing a program called "Online Education System for Higher Education in Indonesia." This program endorsed higher education institutions to implement online and blended learning on their campuses. This program also demands lecturers to be able to design a good online or blended learning program for their classes. So far, in Indonesia, the researcher has not found an ISD model intended explicitly as a guideline for lecturers in creating a course using the blended learning approach. Thus, the existence of this ISD model is imperative to support MoRTHE's program mentioned above.

\section{Methods}

\subsection{Research goal and method}

This study aims to develop an ISD model as a guideline for lecturers in creating a good quality course using a blended learning approach. The objectives are to investi- 
gate the feasibility and usability of the ISD model developed in the context of higher education setting in Indonesia. The development of an ISD model may apply the design and development research approach [13]. Formative research is one of the most appropriate research methods for this kind of study [14]. Formative research is a type of design and development research to develop a particular case (product, event, or both), a learning theory related to a particular case, and descriptive theory related to learning theory [14]. In this case, to develop a design theory (ISD model) that can be used as a guideline for lecturers in Indonesia. Therefore, this study applied the formative research method. As a consequence, the researcher also used a series of formative evaluation, along with several formative data collection techniques required. Formative evaluation and its data collection techniques are essential to evaluate the strengths and weaknesses of the ISD model in its developing stages. So, the researcher can make some revisions to improve the ISD model developed.

\subsection{Sample, procedure, and data analysis technique}

This study employed a purposive sampling method. The researcher purposefully selected a number of peoples to review and evaluate the tentative model developed [15]. In this case, the researcher selected 40 instructional system designer experts, 3 elearning experts, and 235 lecturers as the sample of this study. The close-ended and open-ended questionnaires were used as instrument to collect formative data and information from both experts and lecturers. Those data collection techniques permitting researchers to compare and understand formative data and information obtained [15]. Since rubric assessment is an appropriate instrument to assess performance [16], the researcher used it as another instrument to assess respondents performance in designing a course using the ISD model developed.

This study used formative research procedure as can be described as in Figure 1 below:

As can be shown in Figure 1, the researcher conducted five stages of formative data collection techniques. As the first step, the researcher developed a tentative ISD model. At this stage, based on more than ten years of working in the field of online learning development and implementation, the researcher conducted a literature review and self-evaluation to produce an ISD tentative model. Once the tentative model has been developed, the researcher then, conducted an expert review and one-to-one evaluation [17]. The formative data and information gained from those two steps were used to revise the became the first revised ISD model. As a followed-up, the researcher then sequentially conducted three times field tests. A The field test, also known as field trial, is a process to determine the strengths and weaknesses of education program for the target group in the intended setting [18]. In this case, the researcher conducted a workshop to explain the tentative model, assigned the lecturers to design a course by using the tentative model as a guideline, asked the lecturers to submit the result via email, and conveyed open-ended and close-ended questionnaires to be filled online by the lecturers. The researcher then used rubric assessment to assess course designs created by lecturers using the tentative ISD model. Formative data and information obtained from questionnaires and rubric assessment in field test 1 were used to 
revise the first revised model and became the second revised one. The same procedure then repeatedly used for field test 2 and field test 3 until the final ISD model completed.

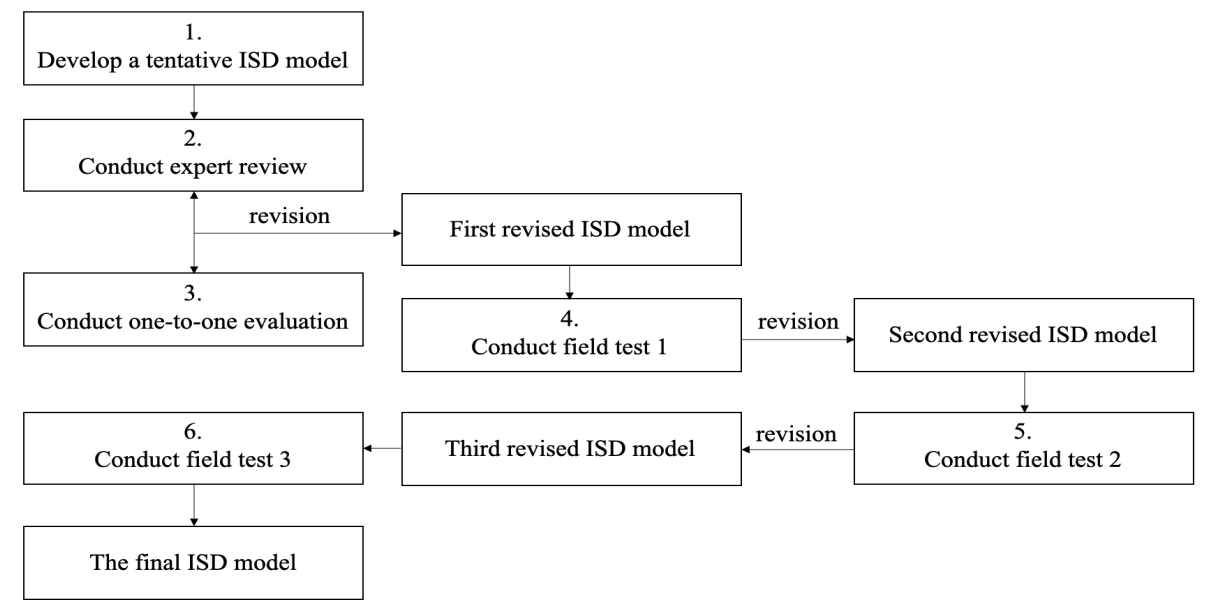

Fig. 1. The procedure of study

Data gained from close-ended questionnaires analyzed quantitatively by using one to five Likert Scale ranged from strongly disagree, disagree, neutral, agree, and strongly agree. A percentage formula was used to calculate the respondent's answer. Data gained from open-ended questionnaires analyzed qualitatively by understanding and interpreting the respondent's responses and inputs. The researcher used a triangulation technique to compare data obtained from close-ended and open-ended questionnaires. Data acquired from rubric analyzed quantitatively by scoring all respondent's performance into poor, fair, good, and excellent scores according to the predetermined rubric descriptor. The researcher then used a triangulation technique to compare the rubric score gained from one-to-one evaluation, field test 1 , field test 2 , and field test 3 as a basis to make a final revision of the ISD model.

\section{$3 \quad$ Results and Discussion}

\subsection{Results}

This study has produced two significant results. They were the conceptual framework of blended learning and the ISD model that serve as a guideline for lecturers in creating a good quality of a course using blended learning approach itself. Some references showed that the term blended learning related to the efforts of providing access to learning resources anytime and anywhere [19] in the context of synchronous and asynchronous learning [20]-[22] with the aim at creating learning experiences [23]. So, based on the references mentioned above, the researcher developed the conceptual framework that can be shown as in Figure 2 below: 


\begin{tabular}{|c|c|c|c|}
\hline \multicolumn{2}{|c|}{ Synchronous Learning } & \multicolumn{2}{|c|}{ Asynchronous Learning } \\
\hline $\begin{array}{l}\text { Live Synchronous Learning } \\
\text { (LSL) }\end{array}$ & $\begin{array}{l}\text { Virtual Synchronous } \\
\text { Learning (VSL) }\end{array}$ & $\begin{array}{l}\text { Self-directed Asynchronous } \\
\text { Learning (SAL) }\end{array}$ & $\begin{array}{c}\text { Collaborative } \\
\text { Asynchronous Learning } \\
\text { (CAL) }\end{array}$ \\
\hline
\end{tabular}

Fig. 2. A conceptual framework of blended learning setting

Figure 2 describes the proposed conceptual framework of blended learning setting viewed from the perspective of time and space (synchronicity). As can be shown in Figure 2, the learning event can be divided into two categories: 1) synchronous learning; and 2) asynchronous learning. The synchronous learning event can be divided into two subcategories: 1) live synchronous learning (LSL); and 2) virtual synchronous learning (VSL). The asynchronous learning event also can be divided into two categories: 1) self-directed asynchronous learning (SAL); and 2) collaborative asynchronous learning (CAL).

LSL is a learning event that occurs at the same time and in the same place. VSL is a learning event that occurs at the same time, but in the different place. SAL is a learning event that occurs at anytime and anywhere independently under their own pace and control (self-directed learning). CAL is a learning event that occurs at anytime and anywhere with someone else. Based on the conceptual framework explained above, the researcher defined blended learning as a form of a learning system that combines synchronous and asynchronous learning strategies appropriately in such a way to create an optimum learning experience to achieve the specific predetermined learning outcomes.

Result of the expert review related to the conceptual framework and definition of blended learning can be shown as in Figure 3 below:

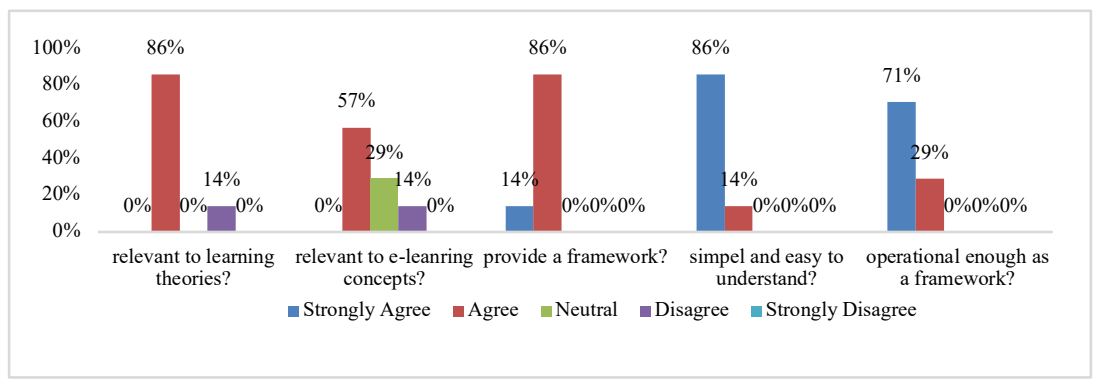

Fig. 3. Result of the expert review related to the conceptual framework and definition of blended learning

Figure 3 describes that most of the experts strongly agree and agree that the conceptual framework and definition of blended learning proposed is relevant to the learning theories and e-learning concepts, provide a framework, simple, and easy to understand. It was also operational enough as a framework. Therefore, conceptual framework and definition can be used as an operational reference to develop the ISD model in this study. 
The second result is the aim of this study. It is a final ISD model that serves as a guideline for lecturers in higher education institutions in Indonesia to create a good quality of a course using a blended learning approach. By referring to the conceptual framework and definition of blended learning explained above, the researcher has developed an ISD model named PEDATI. PEDATI stands for pembelajaran daring di perguruan tinggi [online learning in higher education]. Henceforth, the term PEDATI in this article refers to the ISD model developed in this study. PEDATI has four steps, i.e.: 1) formulating course learning outcomes; 2) mapping and organizing content; 3) determining appropriate learning activities; and 4) designing synchronous and designing asynchronous learning activities. It can be described as in Figure 4 below:

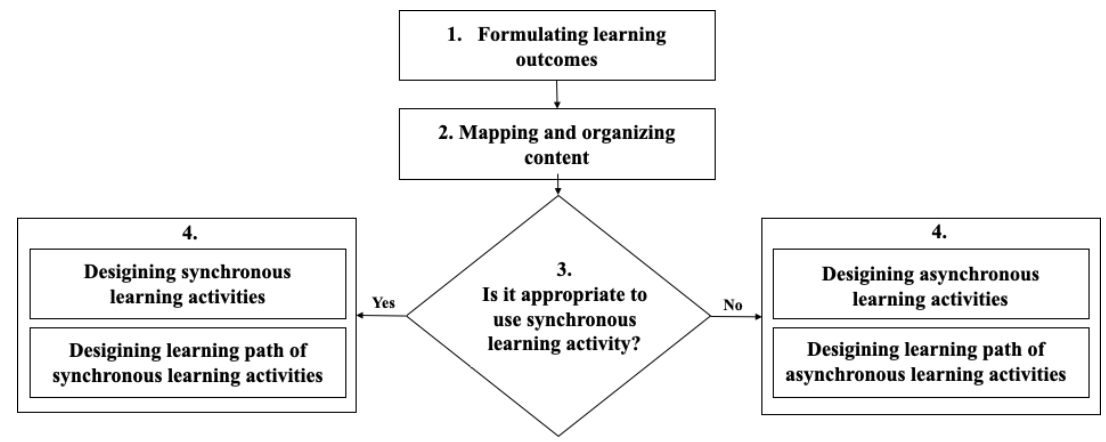

Fig. 4. The developed ISD model, named PEDATI

The result of expert review to the developed ISD model (PEDATI) can be described as in Figure 5 below:

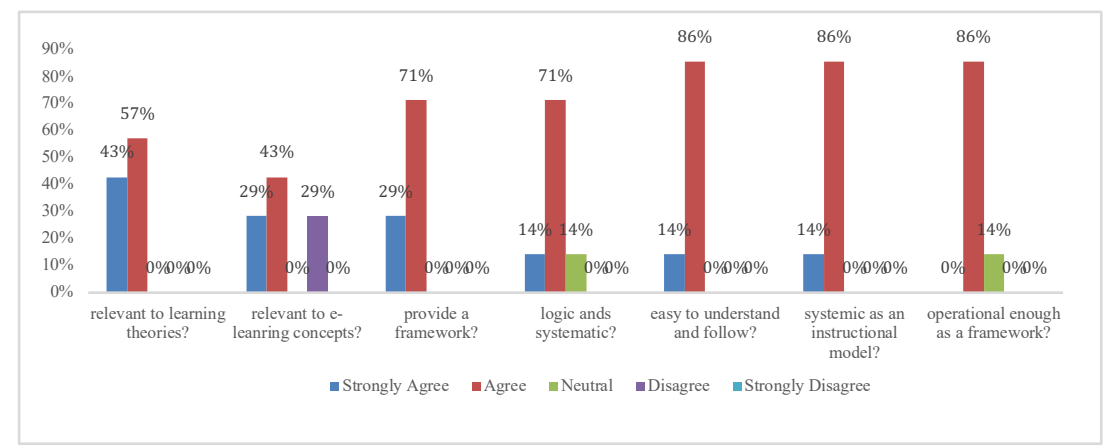

Fig. 5. The result of the expert review related to the ISD model developed

Figure 5 describes that most of the experts strongly agree and agree that PEDATI is relevant to the learning theories and e-learning concepts, provide a framework, systematic, easy to understand and follow, systemic and operational enough as an instructional system design model. 
PEDATI, put learning outcomes as the first step and main foundation that will determine the next steps. For this purpose, the researcher created criteria to formulate good course learning outcomes by referring to the guidelines suggested by some authors (see table 3).

Table 1. The elements of good quality learning outcomes

\begin{tabular}{|l|l|}
\hline \multicolumn{1}{|c|}{ Author } & \multicolumn{1}{c|}{ Learning outcome elements } \\
\hline Mager [24] & $\begin{array}{l}\text { 1. Audience 3. Condition } \\
\text { 2. Behavior 4. Degree }\end{array}$ \\
\hline \multirow{3}{*}{ Kemp at. al. [25] } & 1. Main elements: \\
& $\begin{array}{l}\text { 2. Supporting elements: } \\
\text { Behavior. a. Condition } \\
\\
\text { Dick at. al. [18] }\end{array}$ \\
& Content-references. b. Standard \\
\hline & 2. Behavior (B) \\
& 3. Conditions (CN) \\
\hline
\end{tabular}

The researcher also developed procedures and examples on how to formulate good quality of course learning outcomes. First, pick and specify the most appropriate operational verb (behavior) as an indicator of student learning achievement. Second, determine the conditions (may consist of more than one) in which students must indicate the learning outcomes. Third, determine the criteria or minimum standards (may consist of more than one) where students must indicate the learning achievements. Forth, compose the formulation of course learning outcomes with a certain writing composition. The order of learning outcomes may vary.

The result of the expert review related to the procedure of formulating learning outcomes can be described as in Figure 6 below:

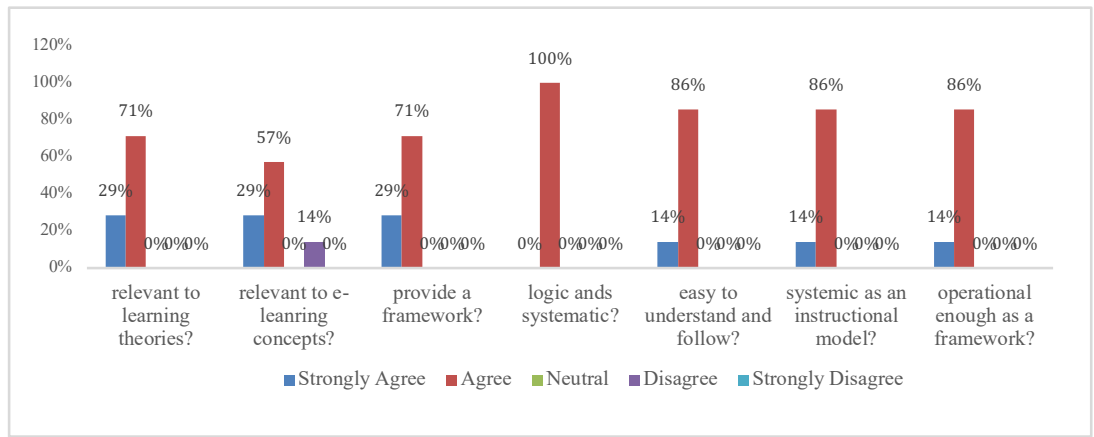

Fig. 6. The result of the expert review related to the procedure of formulating learning outcomes

Figure 6 describes that most of the experts strongly agree and agree that the procedure of formulating learning outcomes is relevant to the learning theories and elearning concepts, provide a framework, systematic, easy to understand and follow, systemic and operational enough as a procedure of an ISD model. 
The second step is mapping and organizing content based on the formulated learning outcomes. This step is an activity to determine and classify learning content in such a way to be more specific logic, and systematic based on predetermined learning outcomes. For this purpose, the researcher provides a template and example of mapping and organizing content (see table 5).

Table 2. Template and example of mapping and organizing content

\begin{tabular}{|c|c|c|}
\hline \multicolumn{3}{|c|}{ Course Learning Outcomes: } \\
\hline \multicolumn{3}{|c|}{$\begin{array}{l}\text { Given a course learning outcome, students (in group consist of } 3 \text { to } 4 \text { ) will be able to design appropriate } \\
\text { learning strategies for one session of training well using a quantum teaching approach. }\end{array}$} \\
\hline \multicolumn{3}{|l|}{ Sub-course Learning Outcome: } \\
\hline \multicolumn{3}{|l|}{ Students will be able to: } \\
\hline \multicolumn{3}{|c|}{ re-explain the principles of managing classroom-based on quantum teaching approach well; } \\
\hline \multicolumn{3}{|c|}{$\begin{array}{l}\text { determine relevant learning activities that fit with the predetermined learning outcomes and characteristic } \\
\text { of learning content; and }\end{array}$} \\
\hline \multicolumn{3}{|c|}{$\begin{array}{l}\text { provide relevant examples of appropriate, and engaging learning activities based on the quantum teaching } \\
\text { approach. }\end{array}$} \\
\hline Topic & Subtopic & Learning Points \\
\hline \multirow{3}{*}{$\begin{array}{l}\text { Designing Instructional Strategies } \\
\text { Using Quantum Teaching Ap- } \\
\text { proach. }\end{array}$} & \multirow{3}{*}{ Quantum Teaching Approach } & $\begin{array}{l}\text { What is Quantum Teaching Ap- } \\
\text { proach? }\end{array}$ \\
\hline & & $\begin{array}{l}\text { Principles of Instruction of Quantum } \\
\text { Teaching }\end{array}$ \\
\hline & & $\begin{array}{l}\text { Engaging Quantum Teaching In- } \\
\text { structional Strategies }\end{array}$ \\
\hline & \multirow{6}{*}{$\begin{array}{l}\text { Engaging Students with Brain- } \\
\text { Friendly Learning Activities }\end{array}$} & Fostering Students Curiosity \\
\hline & & $\begin{array}{l}\text { Encourage Students to Experience } \\
\text { First }\end{array}$ \\
\hline & & $\begin{array}{l}\text { AHA: Fostering Meaningful Learn- } \\
\text { ing }\end{array}$ \\
\hline & & $\begin{array}{l}\text { Let Students Demonstrate on Their } \\
\text { Way }\end{array}$ \\
\hline & & Make Students Experiencing More \\
\hline & & It is Time to Celebrate Success \\
\hline
\end{tabular}

The result of the expert review related to the procedure of mapping and organizing content can be described as in Figure 7 below: 


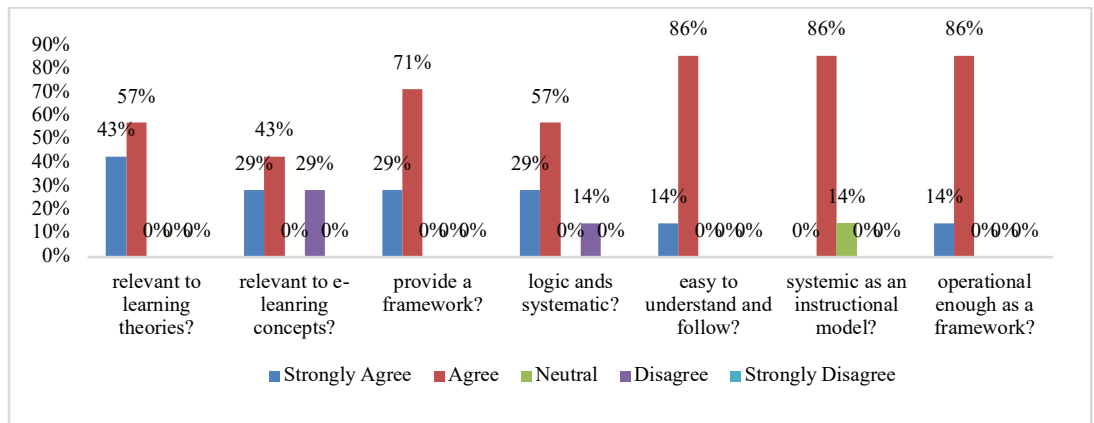

Fig. 7. The expert review result to the procedure of mapping and organizing content

Figure 7 describes that most of the experts strongly agree and agree that the procedure of mapping and organizing content is relevant to the learning theories and elearning concepts, provide a framework, systematic, easy to understand and follow, systemic and operational enough as an instructional system design model.

The third step is determining the appropriate blend of learning activities. This step determines what the most appropriate learning activities with the predetermined learning outcomes and related content are. For this purpose, the researchers created criteria to determine the appropriate blend of learning activities as a guideline. The criteria itself based on the frameworks and definition of blended learning mentioned above. The criteria can be shown as in figure 8 below:

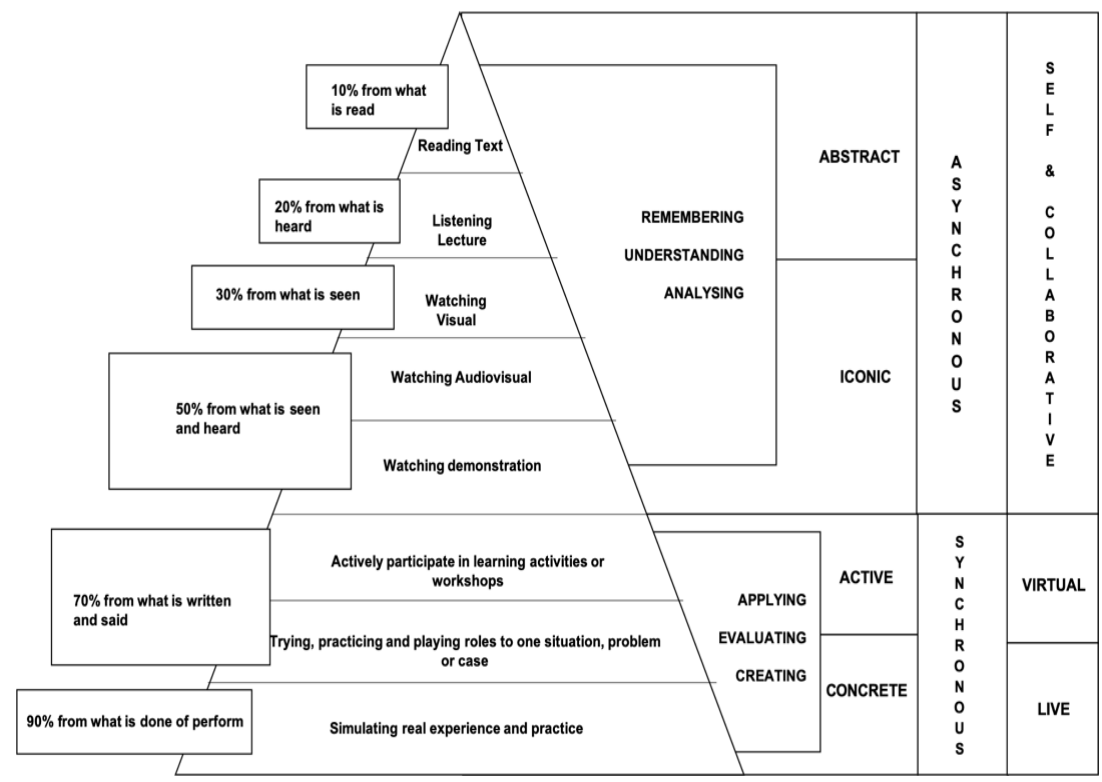

Fig. 8. The Criteria to determine the appropriate mix of blended learning activities 
As shown in Figure 8, the procedure provides a prescription to select and determine the appropriate blend of learning activities. The prescription can be done by asking some questions. First, to achieve predetermined learning outcomes and the characteristics of related content, do we need direct or actual implementation and practice? If yes, then it will be appropriate if we use live synchronous learning (LSL) or face-to-face learning activities. Second, if the answer is not, then asking another question. Does it require active participation, trying, demonstration, and or role play? If yes, then it will be appropriate if we use virtual synchronous learning activity (VSL). Third, if the answer is not, meaning that students can learn by reading, hearing, watching, paying attention, and participating in specific learning activities. Hence, it will be appropriate if we use asynchronous learning activities. It is the combination of both collaborative asynchronous learning (CAL) and self-directed asynchronous learning (SAL) activities.

The expert review results related to the procedure of determining the appropriate combination of learning activities can be shown as in Figure 9 below:

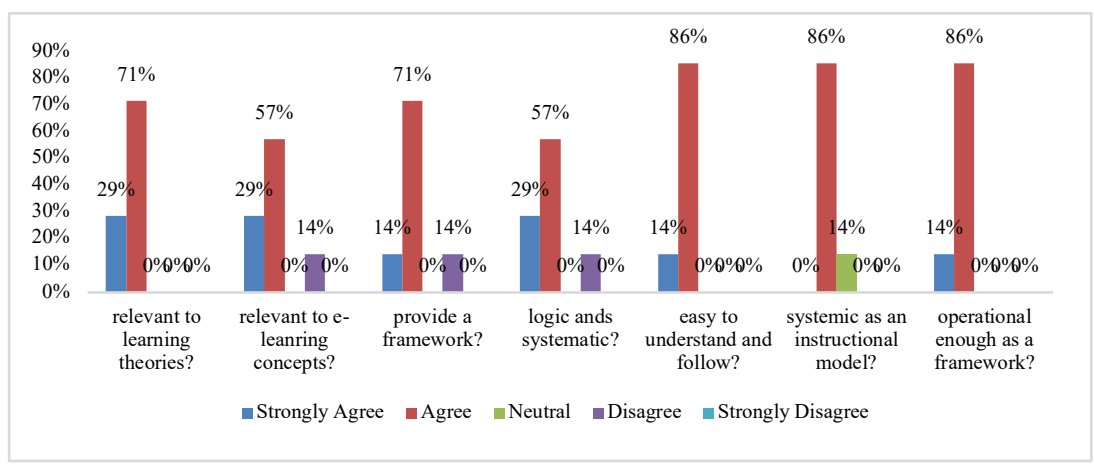

Fig. 9. The result of the expert review related to the procedure of determining the appropriate combination of learning activities

Figure 9 describes that most of the experts strongly agree and agree that the procedure of determining the appropriate combination of learning activities is relevant to the learning theories and e-learning concepts, provide a framework, systematic, easy to understand and follow, systemic and operational enough as an instructional system design model.

The last step is designing synchronous and asynchronous learning activities. The researcher adapted this learning activities model from the work of Horton (2012). According to him, online learning path consists of three steps, i.e. absorb, do, and enact [23]. In this case the researchers developed a learning path model that consists of four steps, i.e. learning, deepening, applying, and evaluating (LDAE). LDAE can be described as in Figure 10 below: 


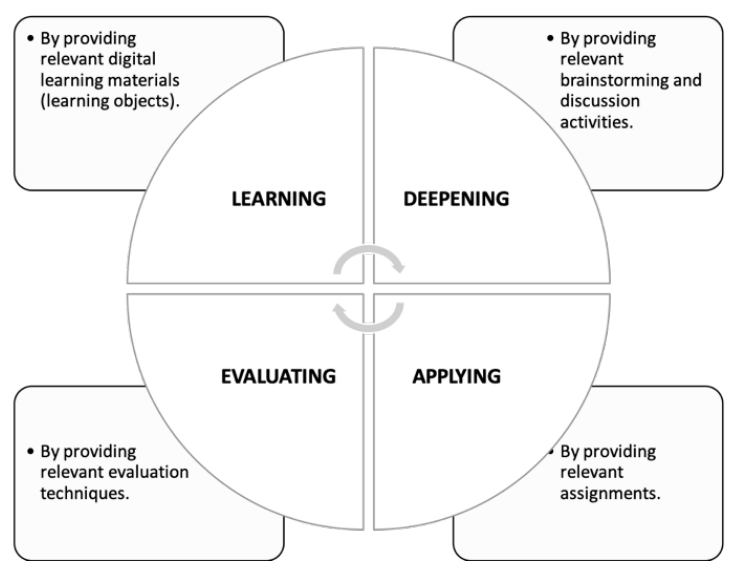

Fig. 10.LDAE: a learning path model in designing synchronous and asynchronous learning

The learning path model consists of four cycles, i.e., learning, deepening, applying, and evaluating (LDAE0. As can be seen in Figure 10, learning activities can be conducted by providing learning objects in the form of text, audio, visuals, videos, animations, simulations, or games. Deepening activities can be conducted by providing an online discussion forum or teleconference. Applying activities can be conducted by providing assignments that can be done either in groups or individually. Evaluating activities can be conducted by providing any kinds of relevant assessment techniques, both objective or non-objective assessment.

Experts review result to the LDAE can be shown as in Figure 11 below:

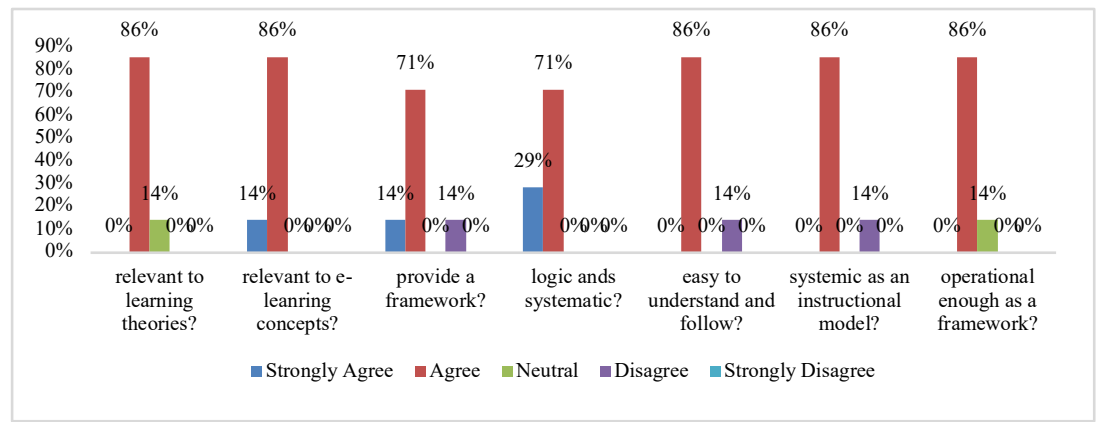

Fig. 11.Result of the expert review related to the procedure of designing synchronous and asynchronous learning activities

Figure 11 describes that most of the experts strongly agree and agree that the procedure of designing synchronous and asynchronous learning activities is relevant to the learning theories and e-learning concepts, provide a framework, systematic, easy to understand and follow, systemic and operational enough as an instructional system design model. 
Open-ended questionnaires conveyed to experts provide some valuable inputs or recommendations the researcher used as a basis to improve this ISD model. It can be shown as in Table 6 below:

Table 3. Inputs and recommendations from experts

\begin{tabular}{|l|l|}
\hline \multicolumn{1}{|c|}{ Inputs from experts } & \multicolumn{1}{|c|}{ Revisions made } \\
\hline $\begin{array}{l}\text { The template is too rigid and demanding so many } \\
\text { requirements. It should be simplified or combine it in } \\
\text { one table or template. }\end{array}$ & $\begin{array}{l}\text { Refine all the templates so that it becomes } \\
\text { simpler and easier. }\end{array}$ \\
\hline $\begin{array}{l}\text { You have to explain more detail the difference } \\
\text { between self-directed asynchronous learning with } \\
\text { collaborative asynchronous learning. You also } \\
\text { should provide some examples of it }\end{array}$ & $\begin{array}{l}\text { Revise the explanation of self-directed asynchronous } \\
\text { learning and collaborative asynchronous learning and } \\
\text { provide some example of learning activities related } \\
\text { to them. }\end{array}$ \\
\hline $\begin{array}{l}\text { All procedures must be clearly explained, complete } \\
\text { with varied examples. }\end{array}$ & $\begin{array}{l}\text { Re-examine the explanation of all procedures and } \\
\text { provide varied examples. }\end{array}$ \\
\hline $\begin{array}{l}\text { You should provide a varied example of an instruc- } \\
\text { tional system design of a particular course using this } \\
\text { ISD model. So, the users will understand the connec- } \\
\text { tion between course learning outcomes, content } \\
\text { organization, learning activities determined, and } \\
\text { learning path designed in one package. }\end{array}$ & $\begin{array}{l}\text { Provide an example of a complete instructional } \\
\text { system design using the tentative model for a certain } \\
\text { course for one semester. }\end{array}$ \\
\hline $\begin{array}{l}\text { It would be better if you provide some cases from } \\
\text { different disciplines such as engineering, art, and } \\
\text { humanity, etc. }\end{array}$ & $\begin{array}{l}\text { The researcher added the examples with some other } \\
\text { different cases from different disciplines. }\end{array}$ \\
\hline $\begin{array}{l}\text { In determining appropriate sync or asynchronous } \\
\text { learning activities, we should consider another } \\
\text { constraint such as time, money, facilities and human } \\
\text { resources availability and readiness. }\end{array}$ & $\begin{array}{l}\text { Putting time, finance, facilities, and human resources } \\
\text { availability and readiness as other criteria to be } \\
\text { considered in determining appropriate synchronous } \\
\text { and asynchronous learning activities. }\end{array}$ \\
\hline
\end{tabular}

The rubric assessment result in a series of field tests also showed that the ability of lecturers to design a good quality course using PEDATI was increased. It can be shown in table 6 below:

Table 4. The increase of lecturer's performance in designing a course using the developed ISD model

\begin{tabular}{|l|c|c|c|c|c|c|}
\hline \multirow{2}{*}{ Score } & \multicolumn{2}{|c|}{ Field test 1 } & \multicolumn{2}{c|}{ Field test 2 } & \multicolumn{2}{c|}{ Field Test 3 } \\
\cline { 2 - 7 } & $\#$ & \% & $\#$ & \% & $\#$ & \% \\
\hline Excellent & 0 & & 85 & 33.6 & 153 & 60.5 \\
\hline Good & 47 & 18.6 & 122 & 48.2 & 85 & 33.6 \\
\hline Fair & 132 & 52.2 & 46 & 28.2 & 15 & 5.9 \\
\hline Poor & 74 & 29.2 & 0 & 0 & 0 & 0 \\
\hline
\end{tabular}

As can be seen in Table 7, the ability of lecturers to create a course using PEDATI was increased. Most of them, $52.2 \%$ get fair scores, and $29.2 \%$ get poor scores on the first field test. The score increased significantly on the field test $2,33.6 \%$ get excellent scores, $48.2 \%$ get good scores, and $28.2 \%$ get fair scores. The score also increased significantly on field test 3 where most of them, $60.5 \%$ get excellent scores, $33.6 \%$ get good scores, and only $5.9 \%$ get poor scores. It means that PEDATI was feasible and usable. 


\subsection{Discussion}

Definition and conceptual framework are essential as a reference for developing an ISD model [26]. They are the key determinant to understand things in a particular context [27]. Therefore, the model developed should be based on a particular conceptual framework. The researcher applied the synchronicity (time and space) perspective as the foundation of the framework. In this case, synchronous and asynchronous learning setting. This foundation, in line with the concept of blended learning proposed by some authors. Some authors define blended learning as the efforts of providing access to learning resources anytime and anywhere [19] in the context of synchronous and asynchronous learning [20] with the aim of creating learning experiences [1]. Another conceptual model is a time-based blended learning model [21]. Based on this conceptual framework, the researcher composed an operational definition of blended learning, as explained above. So, through this study, the researcher would like to provide new different perspective and insight for instructional designers that designing a blended learning course is not merely combining face-to-face with online learning. However, most importantly, it is the art of combining the most appropriate synchronous and asynchronous learning activities to create an optimum learning experience. Therefore, the ultimate goal of blended learning is combining the most appropriate learning technologies and activities both in synchronous or asynchronous learning settings to create optimum learning experiences.

On the other hand, the ISD model is a representation of complex form, process, and function of physical phenomena and ideas [10]. It should have interrelated elements and describe the implementation procedures to produce some key elements of learning, i.e., learners, learning outcomes, learning methods, and evaluation [25]. Therefore, in this study, the ISD model developed represents the procedures that consist of some interrelated elements in it as a system. It is essential since an instructional system should consist of several different elements, but interrelated with each other [25]. As can be seen in figure 4, the ISD model developed has four interrelated and iterative procedures (steps), i.e., formulating course learning outcomes, mapping and organizing content, determining the appropriate learning activities, and designing synchronous and asynchronous learning activities. Each step has a specific function but interrelated with each other.

Learning is an effort to facilitate deliberate study to achieve a predetermined learning goal/achievement. In designing blended learning, the combination (blending) carried out must be addressed to achieve the learning objectives [4]. Driscoll, as cited by Smith and Ragan, defines learning as a deliberate learning condition to encourage the achievement of predetermined learning goals [28]. Thus, predetermined objectives or learning outcomes play a vital role in designing an effective instructional system. Therefore, the researcher put formulating the learning objectives or outcomes as the first step. The researcher also provided a template and examples of how to formulate good objectives based on some author's guidelines.

Another critical factor to be considered in designing blended learning, besides learning objectives, is organizing and mapping content. Well mapped and organized content is critical in designing blended learning. Therefore, the researcher developed a 
procedure of mapping and organizing learning content as the second step. This step provides a guideline for lecturers (instructional designers) to chunk the content in such a way into more detailed pieces of related content. Based on the predetermined course learning outcomes, lecturers (instructional designers) chunk the content into some topics, subtopics, and learning points. Mapping and organizing content procedure developed, is in line with Thorne, Wiley, Mishra, and Koehler's studies. Wiley suggested that the content should be cut off in such a way based on a systematic and logical sequence into a particular learning object [29]. The link between content, pedagogy, and technology is essential [30] to enhance learning interaction and participation [31].

Designing blended learning is challenging. Therefore, careful planning or design is critical [32] [33]. There are some essential questions to be considered in designing blended learning. First, what combination is the most relevant? Second, when is online and or face-to-face learning used? Third, how can the integration of both to achieve learning objectives [3]? Therefore, the researcher developed a procedure to select and determine the relevant learning activities as the third step. It is a procedure that provides criteria to determine when to use synchronous learning and when to use asynchronous learning activities. The researcher adopted Edgar Dale's theory, learning modalities [22], and revised Bloom's taxonomy [34] as a basis to develop this procedure. Some studies showed that choosing relevant learning technologies to improve learning interactions is important [35]. The combination of blended learning must be based on a deep understanding of the strengths and weaknesses of its learning environments. A recent study showed that selecting and utilizing technologies and learning activities appropriately to meet learning outcomes is a matter [36]. Relation among learning objectives, content, and fitness for the purpose of method-in-use, including appropriate learning activities, are key priorities [37] [38]. This step provides a prescription to determine the most appropriate technology and learning activities both in synchronous or asynchronous learning activities according to the characteristics of predetermined learning objectives, content, and existing learning environments.

Interaction is more important and not just the ratio between face-to-face and online learning [39]. Learning activities, both in synchronous and asynchronous learning settings, require a relevant flow of learning interaction, known as the learning path. Learner-instructor and learner-learner interaction [4], student and content [40] are critical factors for the high quality of online learning activities. Therefore, the researcher developed a learning path model named LDAE. It consists of four cycles, i.e., learning, deepening, applying, and evaluating. A recent study showed that understanding student's action [41] and well designed and implemented learning path can increase interaction [42]. Besides, it also affects students' cognitive and emotional engagement [43], interest, and success of learning [27]. The effort to activate students' learning experience is essential in a blended learning environment [26] [43] [45]. Therefore, this ISD model will help lecturers or instructional designers to tailor the flow of learning activities or interactions in such a way to create some engaging students' learning experiences. 


\section{Conclusion and Suggestions}

This study has produced an ISD model as a guideline for lecturers in designing a course with the blended learning approach, named PEDATI. As an ISD model, PEDATI provide interrelated components or procedures. The study results showed that PEDATI and its components were feasible and usable. PEDATI and its components were relevant to the learning theories and e-learning concepts, provide a framework, systematic, systemic, easy to follow, and provide practical guideline for the users. The study result, also showed that lecturer's ability in designing a course using PEDATI improved. Hence, PEDATI can be utilized as a guideline for lecturers in designing good quality of a courses using the blended learning approach.

This study also provides some suggestions for lecturers or instructional designers in designing a course using the blended learning approach. First, it is vital to formulate clear, realistic, and measurable learning objectives since the first place. Second, it is important to organize content as detail as possible into some fragmented or chunked learning points. Third, it is critical to determine which learning points are relevant to be delivered through synchronous or asynchronous learning activities based on the characteristics of the objectives, content, and condition of an existing learning environment. The last, it is also crucial to tailor the learning path using LDAE framework, i.e. learning, deepening, applying, and evaluating cycle of activities in such a way to make learning more interactive, engaging, and meaningful.

\section{$5 \quad$ Limitations}

There are some limitations inherent to the design and implementation of the study. This study conducted in the context of higher education institutions setting in Indonesia. So, the result cannot be generalized in other different contexts. Secondly, this study followed by only 235 lecturers that affecting the quality of this study. Thirdly, this study focus limited to develop the instructional design model at the design stage. Therefore, further study should be conducted that focuses on the development and implementation stage and tested in the broader context.

\section{Acknowledgement}

This study will not succeed without valuable support from related parties. Therefore, the researcher would like to express sincere gratitude and appreciation to the Director of Directorate of Learning and Student Affairs, Ministry of Research, Technology, and Higher Education for her chance and permission to conduct this study in some public and private universities in Indonesia. The researcher also would like to convey much gratitude and high appreciation to all experts and lecturers involved in this study. Without them, this study would be meaningless. 


\section{$7 \quad$ References}

[1] W. Horton, E-learning by design, 2nd ed. San Francisco, CA: Pfeiffer, 2012.

[2] A. Littlejohn and C. Pegler, Preparing for blended e-Learning. 2007.

[3] H. So and C. J. Bonk, "Examining the Roles of Blended Learning Approaches in Computer- Supported Collaborative Learning (CSCL ) Environments: A Delphi Study Blended Learning : From Delivery Technology to Learning Technology," Learning, vol. 13, no. 3, pp. 189-200, 2010. https://doi.org/10.1111/jcal.12201

[4] B. Su, C. J. Bonk, R. J. Magjuka, X. Liu, and S. Lee, "The importance of interaction in web-based education: A program-level case study of online MBA courses," J. Interact. Online Learn., vol. 4, no. 1, pp. 1-19, 2005.

[5] J. Kenney and E. Newcombe, "Adopting a blended learning approach: Challenges encountered and lessons learned in an action research study," J. Asynchronous Learn. Netw., vol. 15, no. 1, pp. 45-57, 2011, https://doi.org/10.24059/olj.v15i1.182.

[6] A. Sun and X. Chen, "Online education and its effective practice: A research reviewmoor," J. Inf. Technol. Educ. Res., vol. 15, no. September 2015, pp. 157-190, 2016.

[7] R. Uz and A. Uzun, "The Influence of Blended Learning Environment on Self-Regulated and Self-Directed Learning Skills of Learners," Eur. J. Educ. Res., vol. 7, no. 4, Oct. 2018, https://doi.org/10.12973/eu-jer.7.4.877.

[8] L. R. Halverson, C. R. Graham, K. J. Spring, J. S. Drysdale, and C. R. Henrie, "A thematic analysis of the most highly cited scholarship in the first decade of blended learning research,” Internet High. Educ., vol. 20, pp. 20-34, Jan. 2014, https://doi.org/10.1016/j.ih educ.2013.09.004.

[9] G. M. Piskurich and J. F. Piskurich, Rapid instructional design: learning ID fast and right, 2nd ed. San Francisco, CA: Pfeiffer, 2006.

[10] K. L. Gustafson and R. M. Branch, Survey of instructional development models, 4th ed. Syracuse, N.Y: ERIC Clearinghouse on Information \& Technology, 2002.

[11] B. B. Seels and R. C. Richey, Instructional Technology: The Definition and Domains of the Field. Bloomington, In.: Information Age Publishing, 2012.

[12] M. Snyder, "Instructional-Design Theory to Guide the Creation of Online Learning Communities for Adults," TechTrends, vol. 53, no. 1, pp. 45-57, Jan. 2009, https://doi.org/10. 1007/s11528-009-0237-2

[13] R. C. Richey and J. D. Klein, Design and development research: methods, strategies, and issues. New York, NY: Lawrence Erlbaum Assoc, 2007.

[14] C. M. Reigeluth, Ed., Building a common knowledge base. New York: Routlegde, 2009.

[15] J. W. Creswell and T. C. Guetterman, Educational research: planning, conducting, and evaluating quantitative and qualitative research. 2019.

[16] S. M. Brookhart, how to create and use rubrics for formative assessment and grading. Alexandria, Virginia: ASCD, 2013.

[17] M. Tessmer, Planning and conducting formative evaluations improving the quality of education and training. London: Routledge, 2016.

[18] W. Dick, L. Carey, and J. O. Carey, The systematic design of instruction, Eighth edition. Boston: Pearson, 2015

[19] B. Holmes and J. Gardner, e - Learning: Concepts and Practice, First Edit. London, New Delhi: SAGE Publication, 2006.

[20] S. Naidu, E-Learning a guidebook of principles, procedures and practices, 2nd ed. New Delhi: Commonwealth Education Media Center for Asia (CEMCA), 2006. 
[21] A. Norberg, C. D. Dziuban, and P. D. Moskal, "A time-based blended learning model," Horiz., vol. 19, no. 3, pp. 207-216, Aug. 2011, https://doi.org/10.1108/1074812111116391 3.

[22] S. E. Smaldino, D. L. Lowther, and J. D. Russell, Instructional technology and media for learning, 10th ed. Boston: Pearson, 2012.

[23] W. K. Horton, E-learning by design, 2nd ed. San Francisco, CA: Pfeiffer, 2012.

[24] R. F. Mager, Preparing instructional objectives: a critical tool in the development of effective instruction, 3rd ed. Atlanta, GA: Center for Effective Performance, 1997.

[25] G. R. Morrison, S. M. Ross, and J. E. Kemp, Designing effective instruction, 5th ed. Hoboken, NJ: J. Wiley, 2007.

[26] R. A. Ellis, A. Pardo, and F. Han, "Quality in blended learning environments - Significant differences in how students approach learning collaborations," Comput. Educ., vol. 102, pp. 90-102, Nov. 2016, https://doi.org/10.1016/j.compedu.2016.07.006.

[27] P. McGee and A. Reis, "Blended Course Design: A Synthesis of Best Practices," Online Learn., vol. 16, no. 4, Jun. 2012, https://doi.org/10.24059/olj.v16i4.239.

[28] P. L. Smith and T. J. Ragan, Instructional design, 3rd ed. Hoboken, N.J: J. Wiley \& Sons, 2005.

[29] D. A. Wiley, Ed., The instructional use of learning objects, 1st ed. Bloomington, Ind: Agency for Instructional Technology: Association for Educational Communications \& Technology, 2002.

[30] P. Mishra and M. J. Koehler, "Technological Pedagogical Content Knowledge: A Framework for Teacher Knowledge," Teach. Coll. Rec., vol. 108, no. 6, pp. 1017-1054, Jun. 2006, https://doi.org/10.1111/j.1467-9620.2006.00684.x.

[31] K. Thorne, Blended Learning: How to Intergrate Online Learning and Traditional Learning. 2003.

[32] M. Glogowska, P. Young, L. Lockyer, and P. Moule, "How 'blended' is blended learning?: Students' perceptions of issues around the integration of online and face-to-face learning in a continuing professional development (CPD) health care context," Nurse Educ. Today, vol. 31, no. 8, pp. 887-891, Nov. 2011, https://doi.org/10.1016/j.nedt.2011.0 2.003.

[33] B. Güzer and H. Caner, "The Past, Present and Future of Blended Learning: An in Depth Analysis of Literature,” Procedia - Soc. Behav. Sci., vol. 116, pp. 4596-4603, Feb. 2014, https://doi.org/10.1016/j.sbspro.2014.01.992.

[34] D. R. Krathwohl, “A Revision of Bloom's Taxonomy: An Overview," Theory Pract., vol. 41, no. 4, pp. 212-218, Nov. 2002, https://doi.org/10.1207/s15430421tip4104_2.

[35] D. Steinman, "Educational Experiences and the Online Student," TechTrends, vol. 51, no. 5, pp. 46-52, Oct. 2007, doi: 10.1007/s11528-007-0069-x.

[36] M. Bower, B. Dalgarno, G. E. Kennedy, M. J. W. Lee, and J. Kenney, "Design and implementation factors in blended synchronous learning environments: Outcomes from a cross-case analysis," Comput. Educ., vol. 86, pp. 1-17, Aug. 2015, https://doi.org/10.1016/ j.compedu.2015.03.006

[37] V. Benson and A. Kolsaker, "Instructor Approaches to Blended Learning: A Tale of Two Business Schools,” Int. J. Manag. Educ., vol. 13, no. 3, pp. 316-325, Nov. 2015, https:// doi.org/10.1016/j.ijme.2015.10.001

[38] N. Uosaki, H. Ogata, M. Li, B. Hou, and K. Mouri, "Guidelines on Implementing Successful Seamless Learning Environments: a Practitioners' Perspective,” Int. J. Interact. Mob. Technol. IJIM, vol. 7, no. 2, pp. 44-53, Apr. 2013, https://doi.org/10.3991/ijim.v7i2.2467.

[39] K. F. Hew and W. S. Cheung, Using Blended Learning. Singapore: Springer Singapore, 2014. 
[40] Ç. S. Çardak and K. Selvi, "Increasing teacher candidates' ways of interaction and levels of learning through action research in a blended course," Comput. Hum. Behav., vol. 61, pp. 488-506, Aug. 2016, https://doi.org/10.1016/j.chb.2016.03.055.

[41] N. U. Bhaskar, S. N. Raju, G. Paladugu, and V. Reddy, "Aspects of Content, Context and Adaptation Modeling in Mobile Learning Application Design,” Int. J. Interact. Mob. Technol. IJIM, vol. 7, no. 2, pp. 29-37, Apr. 2013, https://doi.org/10.3991/ijim.v7i2.2338.

[42] P. Baepler, J. D. Walker, and M. Driessen, "It's not about seat time: Blending, flipping, and efficiency in active learning classrooms," Comput. Educ., vol. 78, pp. 227-236, Sep. 2014, https://doi.org/10.1016/j.compedu.2014.06.006.

[43] K. C. Manwaring, R. Larsen, C. R. Graham, C. R. Henrie, and L. R. Halverson, "Investigating student engagement in blended learning settings using experience sampling and structural equation modeling," Internet High. Educ., vol. 35, pp. 21-33, Oct. 2017, https:// doi.org/10.1016/j.iheduc.2017.06.002

[44] M. A. Ghufron and F. Nurdianingsih, "Flipped Teaching with CALL in EFL Writing Class: How Does It Work and Affect Learner Autonomy?," Eur. J. Educ. Res., vol. 8, no. 4, Oct. 2019, https://doi.org/10.12973/eu-jer.8.4.983.

[45] R. Earnshaw, "From E-Learning to M-Learning - the use of Mixed Reality Games as a new Educational Paradigm," Int. J. Interact. Mob. Technol. IJIM, vol. 5, no. 2, pp. 17-25, Apr. 2011, https://doi.org/10.3991/ijim.v5i2.1463

\section{Authors}

Uwes Anis Chaeruman is a lecturer in the Department of Educational Technology, Faculty of Educational Science, State University of Jakarta. He has been teaching instructional design, instructional media development, and e-learning design for more than seven years. Right now, his interest is in e-learning, especially blended learning design and implementation.

Basuki Wibawa is a professor of educational technology in the Post Graduate Program, State University of Jakarta. His interest is in instructional system design, human performance technology, management of educational technology, and educational technology for vocational education.

Zulfiaty Syahrial is a senior professor of educational technology in the Post Graduate Program, State University of Jakarta. Her interest is in instructional system design and program evaluation.

Article submitted 2020-03-26. Resubmitted 2020-04-18. Final acceptance 2020-04-20. Final version published as submitted by the authors. 